\title{
Morphofunctional and Hematological Characteristics of Health in Students from the Northern and Southern Regions of Kazakhstan
}

\author{
Saule Bazarbaeva ${ }^{1,2}$, Aigul Dinmukhamedova ${ }^{2 *}$, Gulnara Tleubergenova ${ }^{1}$, Zhanar Rakhimzhanova ${ }^{3}$, Kamila Sembekova ${ }^{3}$, \\ Sholpan Karbayeva ${ }^{4}$ Elmira Kuandykova ${ }^{4}$ \\ ${ }^{1}$ Department of Biology, M. Kozybayev North-Kazakhstan State University, Petropavlovsk, Kazakhstan; ${ }^{2}$ Department of \\ General Biology and Genomics, L.N. Gumilyov Eurasian National University, Nur-Sultan, Kazakhstan; ${ }^{3}$ Department of Normal \\ Physiology, Astana Medical University, Nur-Sultan, Kazakhstan; ${ }^{4}$ Department of Geography, Ecology and Tourism, Abai Kazakh \\ National Pedagogical University, Almaty, Kazakhstan
}

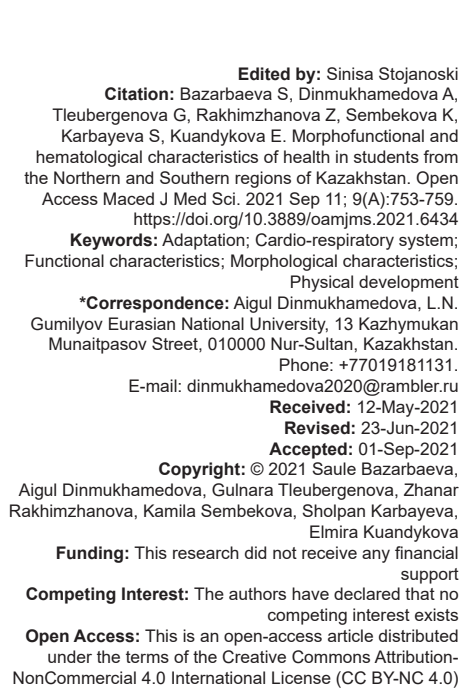

\begin{abstract}
BACKGROUND: Over the past decade, the Republic of Kazakhstan has undergone various socio-economic transformations, which have revealed many negative factors affecting the health and quality of life of the population especially the younger generation.

AIM: The study aim is to study the morphofunctional and hematological parameters of the 1st year university students.

METHODS: The health status for a total of $4001^{\text {st }}$-year students, who arrived for studying from the northern regions (North Kazakhstan, Petropavlovsk) and the southern regions (Turkestan, Kyzylorda), was evaluated during the study. The study investigated some morphological and functional parameters of the organism (body length, body mass index, chest circumference, vital lung capacity, vital index, blood pressure, heart rate, etc.), and hematological indicators (the total number of red blood cells, white blood cells, the concentration of hemoglobin in the blood, etc.) The results were processed by means of variational and differential statistics.

RESULTS: Comparing the physical health of students from both regions, a significant difference in main morphofunctional and hematological indices has been established. The functional indicators of the cardiovascular and respiratory systems were higher in students from the southern regions, which reflected a good adaptive reaction to studying at the university, as well as new climatic and geographical conditions. Students from the southern regions were reported to have lower red blood cell amounts and mild anemia compared to those from the northern regions.

CONCLUSION: Therefore, constant monitoring of the health state among youth is required to develop effective
\end{abstract} tactics for the students' smooth adjusting to living in new social and climatic conditions.

\section{Introduction}

In recent decades, different socio-economic transformations that occurred in the Republic of Kazakhstan revealed many negative phenomena conceivably affecting the state of health and quality of life of the population. This particularly concerns the deterioration of health among the younger generation [1], [2]. It has been shown that the pace of morphological and functional development in youth and their health state depend not only on the gene pool but to a large extent on environmental factors [3], [4].

Residents of various climatic-geographic zones differ in morphological parameters, as well as by the specifics of metabolic processes in each region [5], [6].

The Government of the Republic of Kazakhstan has adopted and is implementing the Serpin-2050 social project, according to which preferential state educational grants are provided for applicants from the southern regions at universities in Northern Kazakhstan. This project can allow equalizing the regional imbalance in the employment market, which is caused by low birth rates and external migration in the northern part of the country [7].

At the same time, some researchers note that the process of adaptation of an average healthy person to the climatic and social conditions is accompanied by fairly pronounced changes in all systems involved in the oxygen supply of tissues. Initial changes at the biochemical, cellular, and tissue levels are manifested afterward in the functional changes of the respiratory system, blood circulation, and red blood cells. The blood circulation system plays a dominant role in maintaining homeostasis in constantly changing environmental conditions and is one of the first to be included in the adaptation process [8], [9], [10], [11], [12].

Based on the foregoing, research was undertaken to investigate the morphofunctional and hematological indicators of the health state among 
$1^{\text {st }}$-year students, who came to study from the northern and southern regions of the Republic.

\section{Methods}

The study was conducted on the basis of M. Kozybaev North Kazakhstan State University in September of 2018-2019 academic year. The study included $17-18$ years old $1^{\text {st }}$-year students (200 girls and 200 boys of Kazakh nationality). The participants were selected by age, gender, and place of residence (north, south); residence in the region from birth to the present time was taken into account. All participants belonged to health Groups 1 and 2; in other cases, participants were excluded from the study. The study design included the assessment of morphological, physiological, and hematological characteristics of $1^{\text {st }}$-year students. The morphological and functional indicators of the students' health were studied in the medical office of the university using standard equipment (height meter, scales, portable dry spirometer SPP, tonometer, and electrocardiograph "Axion EK 1T-07").

Anthropometric parameters were evaluated by $\mathrm{BL}, \mathrm{BM}$, and chest chest circumference $(\mathrm{CHC})$. According to obtained $\mathrm{BL}, \mathrm{BM}$, and $\mathrm{CHC}$ values, the body mass index (BMI), stenium (SI), and Pinier (PI) indices were calculated [13]. The type of constitution was determined according to Chernorutsky [14].

The indexes of stenium and Pinier were used to assess individual constitutional type.

$$
\mathrm{SI}=\mathrm{BL}, \mathrm{cm} /(2 \times \mathrm{BM}, \mathrm{kg}+\mathrm{CHC}, \mathrm{cm})
$$

The SI value above 1.25 indicates the predominance of the dolichomorphic body type, SI within the range of $0.85-1.25$ expresses the mesomorphic type, and below 0.85 assumes the brachymorphic type [15].

$$
\mathrm{PI} \mathrm{BL}, \mathrm{cm}-(\mathrm{BM}, \mathrm{kg}+\mathrm{CHC}, \mathrm{cm})
$$

When assessing the Pinier index, the value above 30 is typical for asthenic body type, within the range from 10 to 30 characterizes the normostenic body type, and below ten assumes that of hypersthenic [14].

For the experiment, the following functional parameters were determined:

1. The strength of the hands $(\mathrm{SH})$ with the help of dynamometer and hand force index (HFI) by the formula:

$\mathrm{HFI}=\mathrm{SH}(\mathrm{kg}) / \mathrm{BM}(\mathrm{kg})$

2. Vital lung capacity (VC) with the help of air spirometer and vital index (VI) by the formula: $\mathrm{VI}=\mathrm{VC}(\mathrm{ml}) / \mathrm{BM}(\mathrm{kg})[15]$.

To assess the individual value of $\mathrm{VC}$, it was compared with VC (ShVC) based on indicators of body length $(B L)$ and body mass (BM). The ShVC (ml) was calculated by the following formulas:

$$
\begin{aligned}
& \text { for males: ShVC=40×BL }(\mathrm{cm})+ \\
& 30 \times B M(k g)-4400 \\
& \text { for females: ShVC=40×BL (cm)+ } \\
& \text { 10×BM (kg)-3800 }
\end{aligned}
$$

The functional efficacy of the cardiovascular system in conditions of relative rest was evaluated by the double product (DP):

$$
\mathrm{DP}=(\mathrm{SBP} \times \mathrm{HR}) / 100
$$

where SBP is systolic blood pressure $(B P)$ in $\mathrm{mm} \mathrm{Hg}$, and $\mathrm{HR}$ is the heart rate in bpm [14], [15].

To assess the functioning level of the blood circulatory system, the adaptive potential (AP) was applied [14].

Calculation of AP (in points) was carried out according to the formula:

$$
\begin{aligned}
A P= & 0.011(\mathrm{HR})+0.014(\mathrm{SBP})+0.008 \\
& (\mathrm{DBP})+0.014(\mathrm{~A})+0.009(\mathrm{BM})-0.009 \\
& (\mathrm{BL})+0.004(\mathrm{G})-0.273
\end{aligned}
$$

where $\mathrm{HR}$ is the heart rate (HR), bpm; SBP; and $\mathrm{DBP}$ are systolic and diastolic $\mathrm{BP}$, respectively, $\mathrm{mmHg}$; $A$ is the age, years; $B M$ is the body mass, $\mathrm{kg}$; $\mathrm{BL}$ is the body length, $\mathrm{cm}$; and $\mathrm{G}$ is the gender (male -1 and female -2 ). The results were evaluated by the following parameters: satisfactory adaptation - no more than 2.10 points, adaptation stress - from 2.11 to 3.2 , unsatisfactory adaptation - from 3.21 to 4.3 , and failure of adaptation - from 4.31 and higher [16].

Assessment of the main characteristics of peripheral blood was carried out based on the Regional Blood Center of Petropavlovsk. Counting and differentiation of the formed elements of peripheral blood were performed by an automatic hematological analyzer "Sysmex XS-1000i" (Sysmex Corporation, Japan). Blood sampling was taken from all study participants in the morning on an empty stomach. The analysis of peripheral blood parameters included the total number of red blood cells, white blood cells, and the concentration of hemoglobin in the blood. Erythrocyte indices were examined as well, namely, the average corpuscular volume of an erythrocyte and the average content and concentration of hemoglobin in an erythrocyte.

The results were processed by means of variational and differential statistics applying non-parametric Student's criteria for independent samples at a significance level of $p \leq 0.05$.

All students gave their voluntary consent to take part in the study. The study design was adopted by Ethical Committee of M. Kozybayev North Kazakhstan State University (protocol No. 6 of 27 Jun 2018). 


\section{Results}

Anthropometric indicators largely depended on the place of previous residence. Students of both sexes from the southern regions had higher body mass and $\mathrm{CHC}$ indices, while the $\mathrm{BL}$ value was higher for northern residents in all studied groups (Table 1).

Table 1: Anthropometric parameters of students from the northern and southern regions

\begin{tabular}{lllll}
\hline Indicators & $\begin{array}{l}\text { Women of the } \\
\text { northern regions } \\
(\mathrm{n}=100)\end{array}$ & $\begin{array}{l}\text { Women of the } \\
\text { southern regions } \\
(\mathrm{n}=100)\end{array}$ & $\begin{array}{l}\text { Men of the } \\
\text { northern regions } \\
(\mathrm{n}=100)\end{array}$ & $\begin{array}{l}\text { Men of the } \\
\text { southern regions } \\
(\mathrm{n}=100)\end{array}$ \\
\hline Height, $\mathrm{cm}$ & $162.3 \pm 0.4$ & $160.1 \pm 0.3^{\#}$ & $172.1 \pm 0.4^{*}$ & $171.8 \pm 0.3^{*}$ \\
Weight, $\mathrm{kg}$ & $56.8 \pm 0.6$ & $60.2 \pm 0.8^{\#}$ & $71.1 \pm 0.4^{*}$ & $73.8 \pm 0.4^{* \#}$ \\
$\mathrm{CHC}, \mathrm{cm}$ & $82.9 \pm 0.5$ & $88.06 \pm 0.6^{\#}$ & $91.8 \pm 0.4^{*}$ & $95.04 \pm 0.4^{*}$ \\
\hline *0.05, significant differences between the students of different sex. ${ }^{*}$ Significant differences between the \\
students of different regions. CHC: Chest circumference.
\end{tabular}

A qualitative assessment of anthropometric parameters was given based on the BMI. An analysis of the BMI showed that male and female students from the southern regions had a higher rate than those from northern parts of the country.

Moreover, the BMI in students from the southern regions corresponded to "increased fatness," and in the inhabitants of the northern regions, this indicator had the normal value (Table 2).

Table 2: Indices of students' physical development

\begin{tabular}{lllll}
\hline Indicators & $\begin{array}{l}\text { Women of the } \\
\text { northern regions } \\
(n=100)\end{array}$ & $\begin{array}{l}\text { Women of the } \\
\text { southern regions } \\
(n=100)\end{array}$ & $\begin{array}{l}\text { Men of the } \\
\text { northern regions } \\
(n=100)\end{array}$ & $\begin{array}{l}\text { Men of the } \\
\text { southern regions } \\
(n=100)\end{array}$ \\
\hline $\begin{array}{l}\text { Body mass } \\
\text { index, } \mathrm{kg} / \mathrm{m}^{2}\end{array}$ & $21.6 \pm 0.2$ & $23.5 \pm 0.3^{\#}$ & $24.02 \pm 0.1^{*}$ & $25.02 \pm 0.1^{*}$ \\
$\mathrm{Pl}, \mathrm{c} . \mathrm{U}$ & $22.5 \pm 1.01$ & $11.8 \pm 1.3^{\#}$ & $9.1 \pm 0.8^{*}$ & $2.9 \pm 0.7^{*}$ \\
\hline $\begin{array}{l}\text { * } \leq 0.05 \text { Significant differences between the students of different sex. }{ }^{*} \text { Significant differences between the } \\
\text { students from different regions. Pl: Pinier index. }\end{array}$
\end{tabular}

The Pinier index, which characterizes the type of physique of a person, was higher in the group of students from the northern regions compared to representatives of the southern regions. Young men in both groups had a hypersthenic type of constitution, while the women of the northern regions had the Pinier index values consistent with the normosthenic type, while the students from the southern regions tended to have hypersthenia (Table 3 ).

Table 3: Distribution of students by body weight (\%)

\begin{tabular}{|c|c|c|c|c|c|c|}
\hline \multirow[t]{2}{*}{ Group } & \multicolumn{2}{|c|}{ Weight loss } & \multicolumn{2}{|c|}{ Standard } & \multicolumn{2}{|c|}{ Weight excess } \\
\hline & Women & Men & Women & Men & Women & Men \\
\hline North & 10 & 0 & 77 & 66 & 13 & 24 \\
\hline South & 8 & 0 & 58 & 71 & 34 & 29 \\
\hline
\end{tabular}

It is shown in Table 3, among the women of the southern regions, persons with excess body weight prevailed, while the majority of women from the northern regions had the normal body weight. In young men, a lack of body weight was not observed, and an excessive body weight was observed in $24 \%$ of young men of northern and $29 \%$ of the southern regions.

An assessment of the wrist dynamometry among students depending on the place of residence showed that men and women from the southern regions of the Republic had higher indicators of the strength of their right and left hands (Table 4).
Table 4: Functional parameters of body

\begin{tabular}{lllll}
\hline Indicators & $\begin{array}{l}\text { Women of the } \\
\text { northern regions } \\
(n=100)\end{array}$ & $\begin{array}{l}\text { Women of the } \\
\text { southern regions } \\
(n=100)\end{array}$ & $\begin{array}{l}\text { Men of the } \\
\text { northern regions } \\
(n=100)\end{array}$ & $\begin{array}{l}\text { Men of the } \\
\text { southern regions } \\
(n=100)\end{array}$ \\
\hline $\mathrm{HFI}, \mathrm{kg} / \mathrm{kg}$ & $55.1 \pm 1.07$ & $64.03 \pm 1.1^{\#}$ & $70.6 \pm 0.9^{*}$ & $72.7 \pm 0.7^{*}$ \\
$\mathrm{Vl}, \mathrm{ml} / \mathrm{kg}$ & $52.6 \pm 0.8$ & $57.1 \pm 1.1^{\#}$ & $59.1 \pm 0.9^{*}$ & $62.7 \pm 1.0 *^{*}$ \\
$\begin{array}{l}\text { Adaptive } \\
\text { potential, c.u }\end{array}$ & $1.8 \pm 0.01$ & $2.1 \pm 0.02^{\#}$ & $2.04 \pm 0.01^{*}$ & $2.2 \pm 0.0$ * $^{*}$ \\
\hline
\end{tabular}

${ }^{*} \leq 0.05$ Significant differences between the students examined by gender. ${ }^{*}$ Significant differences between the students examined by regions. HFI: Hand force index, VI: Vital index.

Young men who came to study from the southern regions had higher absolute values of hand dynamometry that indicated the higher functional capabilities of the muscular system. Since the absolute values of wrist dynamometry cannot give a complete understanding of functional differences, the calculated wrist index was applied, which showed the relation between the strength of the hands and the body weight. According to the carpal index, students of the southern regions also had higher rates compared to those from the northern regions.

When examining the indicators of the respiratory system functional state, the value of vital capacity for students in the northern regions was noted to be generally lower than the age-appropriate due values, while for the students from the southern regions, the $\mathrm{VC}$ indicators were normal (Figure 1).

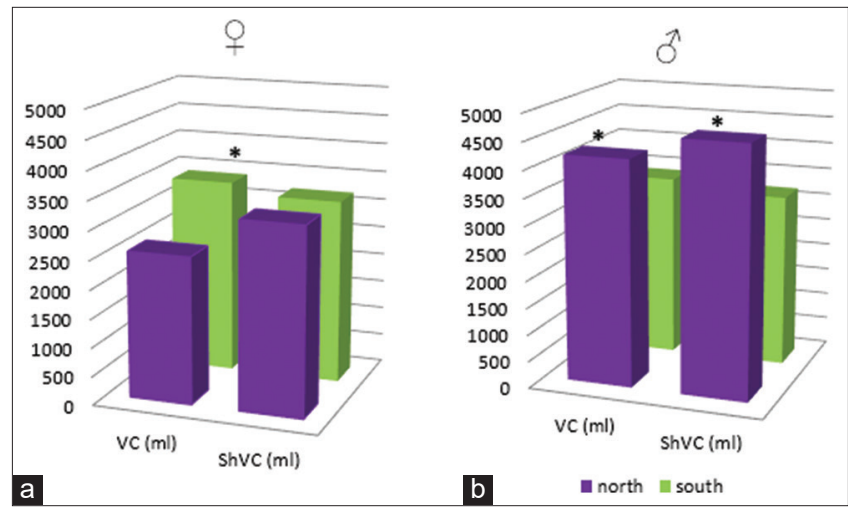

Figure 1: Functional state of the respiratory system of students from the northern and southern regions. ${ }^{*} \leq 0.05$ significant differences between students from the northern and southern regions; (a) Women; (b) Men; VC: Vital capacity, ShVC: Should vital capacity

During the study, it has been established that in students from the southern regions, the HR at rest, as well as SBP and DBP values were higher than similar indicators of people living in the north of the Republic. Thus, BP indicators express the regional differences, which can be attributed to a higher stress level of the functional state of the cardiovascular system in the process of students' adaptation to new climatic and geographical conditions (Figure 2).

Given the indicators of physical development, the level of physical health, and functional reserves of the body were estimated. More than half of the $1^{\text {st }}$-year students from both regions had an average level of physical health, namely, for the northern regions - 59\% female and $47 \%$ male students, and for the southern regions $-44 \%$ female and $49 \%$ male students. At that, the level of health in about $30 \%$ of women and $19 \%$ 


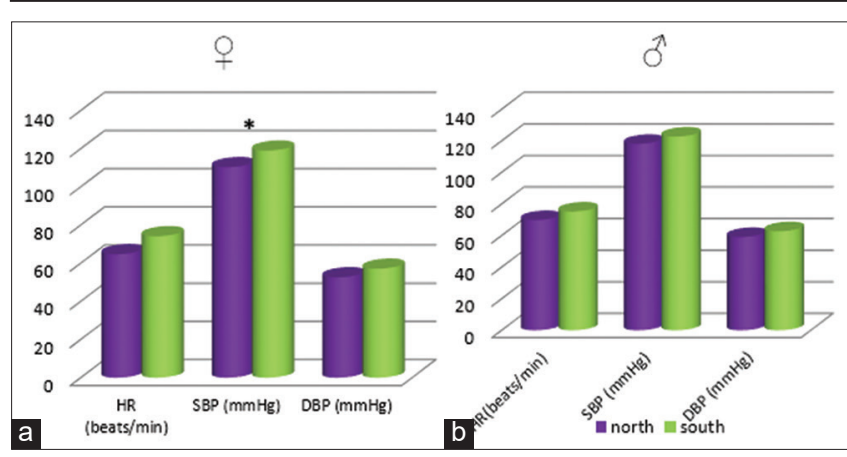

Figure 2: Indicators of the cardiovascular system functioning in students from the northern and southern regions. * $\leq 0.05$ Significant differences between students from the northern and southern regions; (a) Women; (b) men; HR: Heart rate, SBP: Systolic blood pressure, DBP: Diastolic blood pressure

of men from the southern regions was stated as below average.

Among the examined students, low health prevailed among young men of the southern regions and amounted to $27 \%$. In general, when evaluating the level of physical health of the $1^{\text {st }}$-year students according to the method of Apanasenko, students of the northern regions was determined to have an average level of physical health, and for those from the southern regions of the republic, a lower level of health was noted.

The results of studies of blood parameters in students from different climatic and geographical regions are shown in Table 5. It has been established that all the obtained indicators were within referential ranges. However, when comparing the obtained results, some significant differences were noticed. Thus, in residents of the northern regions, the red blood cell counts were higher in comparison with representatives of the south. The hemoglobin content in the blood of students was reported as normal. Although, among women from the southern regions, a deviation from reference values was observed and the hemoglobin level was $108.2 \pm 2.7 \mathrm{~g} / \mathrm{l}$. Studies conducted in the Kyzylorda region among women between 18 and 45 -years-old revealed iron deficiency anemia in $40.2 \%$ of the examined females. This value was significantly higher than that found among women in Europe (14\%), but below-average values among African (48\%) and South Asian women (57\%) [17], [18].

The prevalence of anemia in Kazakhstan among women of reproductive age was about $40 \%$ in 2008 [17].

An important physiological indicator of the body condition is the erythrocyte sedimentation rate (ESR). All obtained ESR values fit into the physiological norm. However, these indicators were lower for young men compared to women. In terms of geographical division, for students from the northern regions, the ESR parameters were $2.7 \pm 0.2$, and for representatives from the southern regions $-9.6 \pm 2.4 \mathrm{~mm} / \mathrm{h}$. Among women, the differences in this parameter were also reported as significant, but less evident.
Table 5: Blood counts for students from the northern and southern regions

\begin{tabular}{|c|c|c|c|c|}
\hline Indicators & $\begin{array}{l}\text { Women of the } \\
\text { northern regions } \\
(n=100)\end{array}$ & $\begin{array}{l}\text { Men of the } \\
\text { northern regions } \\
(n=100)\end{array}$ & $\begin{array}{l}\text { Women of the } \\
\text { southern regions } \\
(n=100)\end{array}$ & $\begin{array}{l}\text { Men of the } \\
\text { southern regions } \\
(n=100)\end{array}$ \\
\hline $\begin{array}{l}\text { The total number } \\
\text { of leukocytes, } \\
\times 10^{9} /\end{array}$ & $6.3 \pm 0.4$ & $6.29 \pm 0.19$ & $5.72 \pm 0.1$ & $5.5 \pm 0.2^{\#}$ \\
\hline $\begin{array}{l}\text { The total number } \\
\text { of red blood } \\
\text { cells, } \times 10^{12} / \|\end{array}$ & $4.5 \pm 0.09$ & $4.75 \pm 0.08^{*}$ & $4.11 \pm 0.06^{\#}$ & $4.5 \pm 0.1^{*}$ \\
\hline $\begin{array}{l}\text { Hemoglobin } \\
\text { concentration, g/l }\end{array}$ & $114 \pm 4.5$ & $139.8 \pm 2.9^{*}$ & $108.2 \pm 2.7$ & $122.9 \pm 4.8^{* \#}$ \\
\hline Hematocrit, $\%$ & $38.6 \pm 1.3$ & $45.3 \pm 0.9 *$ & $36.9 \pm 0.7$ & $41 \pm 0.2^{* \#}$ \\
\hline $\begin{array}{l}\text { The average } \\
\text { volume of the } \\
\text { red blood cell in } \\
\text { the total sample } \\
\text { volume, } \mathrm{fl}(\mathrm{MCV} \text { ) }\end{array}$ & $85.6 \pm 2.5$ & $95.3 \pm 0.7^{*}$ & $90.2 \pm 1.8$ & $90.6 \pm 1.9^{\#}$ \\
\hline $\begin{array}{l}\text { The average } \\
\text { volume of } \\
\text { hemoglobin in } \\
\text { red blood cells, } \\
\text { pg (MCH) }\end{array}$ & $24.9 \pm 1.05$ & $29.3 \pm 0.2^{*}$ & $26.4 \pm 0.6$ & $27.1 \pm 0.7^{\#}$ \\
\hline $\begin{array}{l}\text { The average } \\
\text { concentration of } \\
\text { hemoglobin in } \\
\text { red blood cells, } \\
\mathrm{gm} / \mathrm{dl}(\mathrm{MCHC})\end{array}$ & $28.9 \pm 0.4$ & $30.8 \pm 0.1 *$ & $29.1 \pm 0.2$ & $29.8 \pm 0.3^{\#}$ \\
\hline $\begin{array}{l}\text { Total platelet } \\
\text { count, } \times 10^{9} / 1\end{array}$ & $273.08 \pm 8.2$ & $222.7 \pm 10.6^{*}$ & $322.8 \pm 21.2^{\#}$ & $277.2 \pm 13.2^{\#}$ \\
\hline $\begin{array}{l}\text { Absolute number } \\
\text { of neutrophil, c.u }\end{array}$ & $3.7 \pm 0.3$ & $3.6 \pm 0.4$ & $3.26 \pm 0.1$ & $3 \pm 0.1$ \\
\hline $\begin{array}{l}\text { Absolute } \\
\text { number of } \\
\text { lymphocytes, c.u }\end{array}$ & $2.01 \pm 0.1$ & $1.8 \pm 0.1$ & $1.82 \pm 0.07$ & $1.9 \pm 0.1$ \\
\hline $\begin{array}{l}\text { The absolute } \\
\text { number of } \\
\text { monocytes, c.u }\end{array}$ & $0.49 \pm 0.03$ & $0.6 \pm 0.04 *$ & $0.52 \pm 0.02$ & $0.4 \pm 0.003^{\star \#}$ \\
\hline $\begin{array}{l}\text { The absolute } \\
\text { number of } \\
\text { eosinophils, c.u }\end{array}$ & $0.11 \pm 0.01$ & $0.14 \pm 0.01 *$ & $0.14 \pm 0.02$ & $0.14 \pm 0.01$ \\
\hline $\begin{array}{l}\text { The absolute } \\
\text { number of } \\
\text { basophils, c.u }\end{array}$ & $0.03 \pm 0.005$ & $0.01 \pm 0.001 *$ & $0.02 \pm 0.001$ & $0.02 \pm 0.006$ \\
\hline $\mathrm{ESR}, \mathrm{mm} / \mathrm{h}$ & $13.3 \pm 2.5$ & $2.7 \pm 0.2^{*}$ & $11.0 \pm 1.6$ & $9.6 \pm 2.4^{\#}$ \\
\hline
\end{tabular}

The hematocrit parameters corresponded to standard values. In both gender groups from the northern regions, the obtained rates were higher than in students who came to study from the southern regions. Since the hematocrit reflects a fraction of the blood cell volume, it can be assumed that its increase was associated with an increase in the number of red blood cells in the circulating blood, which in this case was probably due to the stress of the body's adaptive mechanisms

Changes in the general level of leukocyte counts are of great importance since they illustrate the body's response to the action of various exogenous and endogenous factors. A significant decrease in this parameter was revealed among the $1^{\text {st }}$-year students from the southern regions compared to those from the northern part.

As to platelet count among students of both sexes, a significant increase was observed in representatives of the southern regions, which may indicate the sensitivity of hemostasis cells to stressful effects on the body.

When studying erythrocyte indices in students, it has been established that the average erythrocyte 
volume in the total sample volume among women from the southern regions was higher, while among young men from the northern regions of the Republic this parameter was significantly higher.

Changes in blood counts among students from the southern regions of the Republic compared to those from the northern regions indicated the presence of a stress reaction of the blood system when adapting to new climatic, geographical, and social conditions.

\section{Discussion}

The obtained results coincide with the data of Fedorov, who reported the lower values for the functional parameters of external respiration in the male and female population of the northern regions. The level of functioning of the respiratory system largely depends on the students' motor activity and a set of extreme factors (strong winds, low air temperature, daily changes in temperature, atmospheric pressure, etc.) [19].

Satisfactory adaptation, or the first health level, is typical for the most male and female students from the northern regions. Representatives of the southern regions have a lower adaptation potential. The group with functional tension included men and women in the southern regions. These indicators correspond to the stress state of adaptive mechanisms, in which functionality is provided by mobilizing internal reserves. The level of adaptation in males is lower compared to that in females. This can be attributed to their greater sensitivity to environmental changes, psychoemotional condition, and gender characteristics of the cardiovascular system functioning [12], [20], [21].

The study of healthy female students at Taiba University showed that $64 \%$ of students have anemia, and $81 \%$ have a microcytic $(\mathrm{MCV}<80 \mathrm{fL})$ variety [22]. In a study of university students in the province of Hodeida, Yemen, hypochromic anemia was observed in $30.4 \%$ (of which $54 \%$ were women, $46 \%$ were men); $\mathrm{MCV}$ was $72.40 \mathrm{fL}$ for male and $72.30 \mathrm{fL}$ for female [18]. Anemia was observed in 74 students $(33.4 \%)$ out of total 221 students at the University of Faisalabad. Mean \pm SD of MCV of the anemic patients were $78.36 \pm 11.7$ and mean \pm SD of MCV of the normal patients were 81 \pm 13.10 [23]. In studies of Wu et al., it was found that anemia prevails among female sex and is common for the age of 12-17 years. An increased risk of anemia was observed in underweight children from ordinary and poor rural areas. Differences in the risk of anemia depending on latitude were not observed [24]. In the research performed by female medical students in Karad, Maharashtra (India), it has been established that the prevalence of anemia was $28.6 \%$ and was reported as common in both underweight and overweight students [25].
According to Balgimbekov and Tashenova, an increase in the average erythrocyte volume is associated with a positive shift in the prooxidant-oxidative balance in cell membranes, which contributes to an increase in the functional properties of red blood cells [26].

Changes in blood counts among students from the southern regions of the Republic compared to those from the northern regions indicated the presence of a stress reaction of the blood system when adapting to new climatic, geographical, and social conditions.

Thus, a comparative assessment of the physical health of $1^{\text {st }}$-year students who came to study from different regions of the Republic showed significant differences between morphofunctional and hematological parameters. With high probability, this can be attributed to initial climatic and geographical conditions of residence before entering the university, as well as stress response and adaptation of the body to new living conditions in different regions of the Republic.

The obtained materials broaden the understanding of the influence of the complex of morphofunctional and hematological characteristics on the process of adaptation of students to education at the university. The established patterns in the adaptation of students and the data obtained are prerequisites for the creation of regional standards of physical development and functional indicators of students.

The results of the study make a certain contribution to the fundamental provisions of age physiology about the problems of human adaptation and require further research for the optimal organization of educational activities in higher educational institutions.

\section{Conclusion}

$\mathrm{BL}$ indicators of students from the northern regions were significantly higher than those of students from the southern regions, while higher body mass and $\mathrm{CHC}$ indices were recorded for students from the southern regions. The Ketle index was higher among representatives of the southern regions. By the type of physique, hypersthenics prevailed among students from the southern regions, and normostenics commonly represent the northern regions.

For the students from the southern regions, the values of the hand index, VI, HR, and BP were higher than among the northerners, which indicate good muscular development but a higher stress level of the CVS functional state in the process of adaptation.

Most young men and women of the northern regions are characterized by satisfactory adaptation. Representatives of the southern regions have though a lower adaptation potential. An integral indicator 
characterizing the level of physical health showed that a larger percentage of students in the northern regions have an average health condition, while for the students in the southern regions of the Republic, it was reported to be lower.

Blood counts correspond to age and gender standards; however, for the students of the southern regions, a slight degree of anemia was noted. In students from the southern regions, an increase in the indices of platelet link and hematocrit was revealed, which is typical for the adaptation processes of the blood circulation system.

\section{Ethical approval}

The study was conducted in accordance with the ethical principles approved by the Human Experiments Ethics Committee of L.N. Gumilyov Eurasian National University (Protocol № 4 of 22.03.2019).

\section{References}

1. Adilbekova AA, Smagulov NK, Sabiden GS. A comparative assessment of the features of heart rate variability in Kazakhstan and foreign medical students. Mod Probl Sci Educ. 2016;4:83-90.

2. Mukataeva ZM, Kabieva SZ. Monitoring of physical development and health of students in Pavlodar region. Bul NGPU. 2014;1:51-73.

3. Fedewa MV, Das BM, Evans EM, Dishman RK. Change in weight and adiposity in college students a systematic review and meta-analysis. Am J Prev Med. 2014;47(5):641-52. https:// doi.org/10.1016/j.amepre.2014.07.035

PMid:25241201

4. Silventomen K, Jelenkovic A, Sund R. Genetic and environmental effects on body mass index from infancy to the onset of adulthood: An individual-based pooled analysis of 45 twin cohorts participating in the Collaborative. Am J Clin Nutr. 2016;104:371-79. https://doi.org/10.341 O/f.726505636.793547677

5. Allison KR, Irving HM, Adlaf EM, Faulkner GE, Boak A, Manson $\mathrm{HE}$, et al. Ten-year trends in overweight/obesity among Ontario middle and high school students and their use in establishing baseline measures for government reduction targets. Can J Public Health. 2015;106(8):514-19. https://doi. org/10.17269/cjph.106.5175

PMid:26986913

6. Liu Q, Yu C, Gao W, Cao W, Lyu J, Wang S, et al. Genetic and environmental effects on weight, height, and BMI under 18 years in a Chinese population-based twin sample. Twin Res Hum. 2015;5:571-80. https://doi.org/10.1017/thg.2015.63

7. Minister of Education and Science of the Republic of Kazakhstan. Order of the Minister of Education and Science of the Republic of Kazakhstan dated November 26, 2018 No. 646. On the Approval of the Rules for the Organization and Financing of Personnel Training with Technical and Vocational Education, Short-term Vocational Training, According to the Project "Mangilik el Zhastary-industry? ("Serpin"), Retraining of Labor Resources and Redundant Workers, Training of
Qualified Personnel in Demanded Specialties in the Labor Market within the Framework of the "Zhas Maman" Project According to the "100/200" Principle, as Well as Training in the Basics of Entrepreneurship in Organizations of Technical and Professional, Post-secondary Education, Higher and (or) Postgraduate Education. Available form: https://www.online. zakon.kz/document/?doc_id=38280670

8. Zueva OM, Dalenov ED, Slivkina NV. On the formation of the basics of proper nutrition and healthy lifestyles among adolescents and youth in the northern regions of Kazakhstan. Omsk Sci Bull. 2014;(134):115-7.

9. Chandra-Mouli V, Lane C, Wong S. What does not work in adolescent sexual and reproductive health: A review of evidence on interventions commonly accepted as best practices. Glob Health Sci Pract. 2015;3(3):333-40. https://doi.org/10.9745/ ghsp-d-15-00126

10. Min J, Chiu DT, Wang Y. Variation in the heritability of body mass index based on diverse twin studies: A systematic review. Obes Rev. 2013;11:871-82. https://doi.org/10.1111/obr.12065

11. Ndayisaba JP, Fanciulli $A$, Granata R, Duerr $S$, Hintringer $F$, Goebel G, et al. Sex and age effects on cardiovascular autonomic function in healthy adults. Clin Auton Res. 2016;2:169-70. https://doi.org/10.1007/s10286-015-0335-5

12. Hulka OV. Dynamics of spectral indexes of Heart variability rate of the students with different character of the educational loading. Fiziol Zh. 2015;61(4):98-104. https://doi.org/10.15407/ fz61.04.098

PMid:26552312

13. Aizman RI, Lebedev AV, Aizman NI, Rubanovich VB. Methodology and practice of monitoring the health of student youth. Health Educ. 2017;19(5):73-8. https://doi.org/10.26787/ nydha-2226-7425-2017-19-5-73-78

14. Chernorutsky MV. The doctrine of the constitution in the clinic of internal diseases. Proc $7^{\text {th }}$ Cong Russian Ther. 1925;304-12.

15. Aizman RI, Lebedev AV, Aizman NI, Rubanovich VB. Comprehensive Assessment of the Health of Participants in the Educational Process. Moscow: Yurait; 2020.

16. Baevsky RM. The problem of estimation and prognosis of functional state of the organism and its development in space medicine. Success Physiol Sci. 2006;37(3):42-57.

17. Dangour $A D$, Hill HL, Ismail SJ. Original communication haemoglobin status of adult non-pregnant Kazakh women living in Kzyl-Orda region, Kazakhstan. Eur J Clin Nutr. 2001;5:1068-75. https://doi.org/10.1038/sj.ejcn.1601267

18. Al-Alimi AA, Bashanfer S, Morish MA. Prevalence of iron deficiency anemia among university students in Hodeida Province, Yemen. Anemia. 2018;1:4157876. https://doi. org/10.1155/2018/4157876

19. Fedorov VN. Features of Hemodynamics, the Functional State of the Myocardium and the Autonomic Regulation of Cardiac Rhythm in Young People Studying at the University, PhD Dissertation. Kazakhstan: North Kazakhstan State University; 2007

20. Schrimpf A, Kube J, Neumann J, Horstmann A, Villringer A, Gaebler M. Parasympathetic cardio-regulation during social interactions in individuals with obesity. The influence of negative body image. Cogn Affect Behav Neurosci. 2017;17(2):330-47. https://doi.org/10.3758/s13415-016-0482-8 PMid:27905081

21. Tsitsiashvili KS, Kavtaradze GV, Gvaliia MV, Zhorzholiani IR, Makharadze TG. Parameters of circadian heart rate variations, night sleep profile and structure during the Holter monitoring procedure in the groups of students with different adaptation potential. Georgian Med News. 2005;119:52-4 PMid:15834182

22. Al Hassan NN. The prevalence of iron deficiency anemia in 
a Saudi University female students. J Microsc Ultrastruct. 2015;3(1):25-8. https://doi.org/10.1016/j.jmau.2014.11.003 PMid:30023178

23. Jawed S, Tariq S, Tariq S, Kamal A. Frequency of nutritional anemia among female medical students of Faisalabad. Pak J Med Sci. 2017;33(2):398-403. https://doi.org/10.12669/pjms.332.11854 PMid:28523045

24. Wu J, Hu Y, Li M, Chen J, Mao D, Li W, et al. Prevalence of anemia in Chinese children and adolescents and its associated factors. Int J Environ Res Public Health. 2019;16(8):1416.
PMid:31010238

25. Vibhute NA, Shah U, Belgaumi U, Kadashetti V, Bommanavar S, Kamate W. Prevalence and awareness of nutritional anemia among female medical students in Karad, Maharashtra, India: A cross-sectional study. J Fam Med Prim Care 2019;8(7):2369-72. https://doi.org/10.4103/jfmpc.jfmpc_353_19 PMid:31463259

26. Balgimbekov SA, Tashenova GK. Features of hematological parameters in students with different levels of motor activity in modern education. Bul Perm State Univ S Biol. 2014;2:57-60. 